\title{
INNOVATIVE APPROACHES TO LITERARY TEXTS (CHILDREN LITERATURE ON INCLUSION)
}

\author{
OLGA DERKACHOVA, OKSANA TYTUN
}

\begin{abstract}
The research deals with applying to innovative approaches to literary text. Inclusive books for children and ways of working with them at pedagogical faculties are considered. In our research, we will demonstrate the work with such books "Cripple Bunny and his brave mother" by Oksana Drachkovskaya, "Trustees for the Giraffe" by Oksana Luschevska and Yevhenia Haydamaka, "Just because" by Rebecca Elliott, "Magda and her Wind" by Iryna Morykvas, "Planet Willi" by Birta Müller, "Yes! I can!: The girl and her Wheelchair" KendryJ. Barrett, Jacqueline BiuToner, Kler A. Friland, Violet Limey and the trilogy on Pearl of Tuuli Pere. The main heroes of these books are children with disabilities and special educational needs. Narrators mostly are their elder or younger brothers or sisters. The reason of the choosing children's literature on inclusion is that it is modern important literature, which demonstrates the world of children with disability and highlights such serious topics as decease and death. Its aim is to show that variety makes world wonderful and grate. The introduction of holographic design of vita technologies (calligarm, creative games, the pyramid of hero and author) is considered as well, the application of methods of critical thinking (mind-mapping, swot-analysis, six hats, Bloom's taxonomy) in the analysis of fiction is substantiated. Potential online resources helping work with literature are examined. In addition, the possibilities of online resources (rebus, comics' generator, the creating of mind maps, crosswords on different platforms) are determined as important part of the work with text. It has proved that such innovate approaches help to develop creative potential of students, allows analyzing literary text in a new way. Such approaches will be helpful in professional activity of teachers in primary school.
\end{abstract}

Keywords: inclusive literature, hero pyramid, creative game, mind-mapping, swot-analysis, six hats, Bloom's taxonomy, comic book, rebus, Walt Disney triangle.

\section{INTRODUCTION}

The educational space has become different; it is more open and welcoming. Inclusive classes are a real breakthrough in perception and feeling. In this situation, everyone needs to gain a new life experience and learn to make a step forward. Where there is a lack of life experience, one should consult literature. After all, where the answers to questions are not life-giving, they can be found in the books. Many life situations (silence, misunderstanding, harassment, loneliness, bulling, steps to success and hopes) have already been described in literature both from parents' point of view, from the point of view of people with disabilities, and from the point of view of the society where they are. Little and big 
heroes, their defeats and victories, despair and faith, loneliness and a feeling of friendly handshake, love and other pleasures - you can find all these in the books where the main characters are ... No, not those with the special needs ... Where the main characters look for themselves and their place in the world, confront the bulling and believe that the greatest victories are yet to come. These books are about parents' going the hard way from despair to having faith in their children; these books are about pain and unbelievable power of love.

As Olena Osmolovska points out, "the portrayal of characters with disabilities in literature is closely related to the attitude towards disability in this society. Misunderstanding of the nature of disability, its complete rejection in society often led to a certain demonization of literary characters with disabilities. Such heroes were supposed to evoke fear, rejection and, at least, pity and sadness. Often, disability was used to reinforce the character's negative image. This was especially evident in children's literature. A pirate or a thief with some injuries was more frightening. Disability has often been a true companion to poverty and social gaps" [12].

Applying to inclusive literature, introducing it to future teachers is timely, because New Ukrainian School envisages the introduction of inclusive education, which is a "system of state-guaranteed educational services based on the principles of non-discrimination, inclusion of human diversity, effective involvement and inclusion all its participants in the educational process" [2]. Literature or fiction is a key for understanding the problems that a child, teenager, adult with disability has to experience, as it shows the world of such a person with all pain, fears, disappointments, joys, defeats and victories. "It is an interesting story that helps to understand the fact that all people are different. And people with particular features of development, first of all, need perception, accepting and understanding, and then, of course, adequate assistance" [3].

\section{ANALYSIS AND DisCUSSION}

The term "inclusive literature" was introduced into Ukrainian science by the researcher and writer Olena Osmolovska: "Inclusive literature is a literature focused on respectful approach to the rights of people with disabilities and formation of a positive attitude to disability and people with these problems.

Inclusive literature combines the following directions: literature that tells about people with disabilities, forming a positive perception of such people (books that focus the reader's attention on the human qualities and abilities of literary characters with disabilities; who are to make communication with such people mutually interesting and comfortable); literature aimed the perception of personal diversity; literature for children with special educational needs (Braille texts, icons, tactile, picture books, etc.)" [12].

According to Andrews, S.E., literature on disability, inclusive literature, has a definite and important purpose: it can help students become more tolerant of individual characteristics, especially in today's inclusive classes" [1].

Kit Luce in the article "Inclusive Literature: Choosing Resources for Disability at School" writes that diversity representation should include people with disabilities. High quality literature depicting children with disabilities can help create the comprehension of how many children with different opportunities and problems have much in common [8].

Inclusion literature can yield many topics for discussion: labeling, friendship, parents, barriers, school, love, hope and help. "Children's books are powerful; they provide us with a more complex perception of ourselves and others. Readers learn that all characters share universal experiences: dreams, challenges, embarrassments, and triumphs. Children's literature serves innumerable purposes at home and in the classroom. Literature about disabilities, inclusion literature, has a specific and valuable purpose: it can help students become more tolerant of individual differences, particularly in today's inclusive classrooms" [18].

These books have the potential to reduce the feeling of loneliness and isolation among students with disabilities. Inclusive literature is a cheap, fascinating and genuine way of communicating with 
children with disabilities and being able to provide them with stories about themselves, how they cope with their daily routine [2].

Quality literature depicting children with disabilities can help understand how children with different needs and opportunities have much in common [8].

Mary Anne Prater gives some recommendations to librarians, for instance, not to put inclusive literature into a specific category, but to incorporate it into different book categories according to age, genre, etc. However, librarians must be aware of the existence of inclusive books and should professionally offer it [17].

In order to promote inclusive literature, we have introduced a course on "Literature and Inclusion", as well as master classes and public lectures for high school students on a regular basis.

We start introducing inclusive literature with the literature for the little ones. We will discuss the strategies of its analysis in our main body of the article.

We introduce inclusive fiction to students at the discipline "Literature and Inclusion" (specialty "Primary Education"), as well as during master classes on the fiction analysis for high school students.

In our research we'll demonstrate the work with such books "Cripple Bunny and his brave mother" by Oksana Drachkovskaya [5], "Trustees for the Giraffe" by Oksana Luschevska and Yevhenia Haydamaka [9], "Just because" by Rebecca Elliott [7]. In addition to these books, we also offer the students the following books for the youngest: "Magda and her Wind" by Iryna Morykvas[10], "Planet Willi" by Birta Müller [11], and "Yes! I can!: The girl and her Wheelchair" KendryJ. Barrett, Jacqueline BiuToner, Kler A. Friland, Violet Limey [3] and the trilogy on Pearl of Tuuli Pere [14; 15; 16].

First of all, we introduce possible strategies for analysis of fiction, including vita gene holographic technologies, such as: hero pyramid, mental map, creative game, calligraphy, swot-analysis.

The pyramid of the hero is an interesting task as well. Schematically it can be represented like this:

Name of the hero

2 words describing the hero

3 words describing the place of event

4 words describing a problem

5 words describing a plot

6words that help to think about the event in a new way

7words that help to solve the problem.

Mind mapping or mental maps "is a simple and effective technique. It is a method of description of general system of thinking process by means of charts. These maps are created for visualization, structure building and classification of ideas, and also as means of studying, organizing, making decisions while writing articles".

A creative game helps to guess the name of the story or the main hero.

Calligramme is a poetic form in which the words of a poem are arranged to form a pattern suggesting the subject of the poem. The name originates from the collection of poetry Calligrammes: Poems of Peace and War by Guillaume Apollinaire published in French in 1918. In our case Calligramme (graphic riddle) is the description of some text details by using letters of the alphabet, this description helps you to suggest the name of a book. Swot analysisis done according to the following scheme: strength, weakness, opportunities, threats.

We write down the following characteristics of the character: strength, weakness, opportunities, threats. We can pay attention to external and internal factors.

Next stage is to be acquainted with the authors of the books and with the content of the works (briefly), as well as with the background of the books.

Oksana Drachkovska, the writer, journalist, social activist and the winner of the "Coronation of the Word" in the nomination "Plays", living in Chernivtsi tells the following story: "When enrolling in school, my son Nazarchyk (he is 10 years old now, he is in the fourth grade and in a wheelchair) and me went there to solve some problems. Because of visiting schools seldom, Nazarchyk was interested in walking along the corridors; he also wanted to go to the library. Therefore, we were walking along the corridors, when the bell rang and the children ran out of the classrooms to have a break, as it turned 
out, it was the second graders. Being very interested in him, the children surrounded us and started asking questions: "What has happened to him? Why does he have such hands and legs? Is it contagious? Is it cured? Does he get up, or is he sitting all the time?"So many questions and it was unusual for the children. Then I asked them, "Children, have you never seen such a child?" They replied all together: "No!"'The situation gave me a real insight into the problem. I realized the situation we are into ... The problem of the disabled is still closed. It suddenly struck me that the educational improvement should be started with the children who do not know about existence of the peers who are disabled. Initially, I had the idea to write something pedagogical for teachers. Then I remembered that I was a writer and decided to write a fairy tale" [5].

The book tells us a story about Bunny Mom who gave birth to eight bunnies one spring day in the forest. Later it was found out that one rabbit would never be able to jump. Then Dad designed him a wheelchair, and the bunny quickly learned to control it and participated in all the moving games of his friends. However, when the bunny could not get to school because the path to it lies through a stream that cannot be reached by a wheelchair, his Mother goes to the Head of Forest and requires repairing the road and the bridge over the stream. In addition, in a few days the bunny can go to school with everyone. Thanks to the Mom, there is a forest elevator for squirrels with sick paws, a sound traffic light for a blind hedgehog and moles. Forest school teachers learned sign language, and animals with hearing problems were also able to become school members. No one else in the forest was lonely and isolated. In a few years Bunny Mother was elected chairman of the Forest Board. She moved her office to the ground floor and hung a sign "Welcome everyone" on the door. This tale tells us that we are all different, but we do not have to give up even when it is very difficult or unbearable. It is a tale of indifference, mutual understanding and empathy.

Oksana Luschevska's book, (who is a writer, translator, expert on literature, researcher, co founder of the West-East literary and art portal), "Trustees for the Giraffe" considers the problem of environmental problems and inclusion; family support and care. The illustrations were created by Yevhen Haydamak. The main character of the story is the girl Olga who makes a wish in her birthday: "I want to go to the zoo during the whole week!" Her wish comes true. At the zoo she finds out that, it is possible to become an animal guardian. The family begins taking care of the giraffe named Juto. Olya wears an occluder and does not feel comfortable. The writer tells about the origin of the story in this way: "The text was finally made up when I met a girl wearing an occluder to cure the lazy eye. If she does not wear it, then there is a risk that the girl will have a lazy eye. When I met a baby girl Marusia -a happy smiling baby! - who wears a variety of occluders, it became clear for me that it is my key to the text, which was left unwritten ... It is a pity that children wearing occluders are almost absent in children's literature, if it were so, it would help understand and accept this problem by peers. I heard the same idea from Marusia's mother" [20]. Oksana Luschevska's book is not just about love for animals but also about the ability to listen to each other, build a harmonious relationship in the family and with the environment.

Rebecca Elliott is a British writer, illustrator, and author of the Toby and Clemmie books, her own children have become the prototypes for them. Her great love and first passion was to picture - books, because, according to the author, there is nothing more beautiful and perfect than the combination of words and pictures from which a good story emerges. "Just Because" helps children understand that each of us is special, we are all different. A nice and warm story was written on behalf of the brother Toby. According to the story, he has an elder sister, who cannot do as much as he can, but it does not mean that he loves her less: "My elder sister Clemmie is my best friend. She cannot walk, talk, move much... cook pasta, fly the airplane, and do algebra tasks. I do not know why she does not do it all. Just because". She is like a princess who does nothing, but just beautiful - just because. Sisters can be naughty, screaming, annoying. Why? Just because. However, Clemmie is not like that. The phrase "Just Because" ends on every page of the book. Together with his sister, he explores and learns much about the world. He reads books with her, looks at pictures and falls asleep. He does not care that Clemmie is not like other sisters: "Some boys have little sisters. They yell and scream, pull the hair, steal cookies, and do not play cowboys. I do not know why they do it. Just because" [7]. 
He loves her, because true love has no prejudices. And he loves her just because: "And when I go to bed, close my eyes, and start dreaming of ice cream and acorns, Clemmie quietly hugs me and waits for me to fall asleep. Clemmie is my best friend, I love her. And I know exactly why: just because".

"Magda and her Wind" is a story about Magda, the girl who dreams of travelling but is forced to sit in a wheelchair. However, her imagination is so fertile, and the desire is so strong that Magda's dream will surely come true! The author says: "First of all, my book is for children who can go, they have this gift, and for those who do not have this gift. I would like very much my book to be read by the children who cannot go, to encourage them, to dream, to make them believe that they can achieve more than they think. Moreover, I would like to see the book read at home by parents with their children. Magda lives in this world, on the big planet. I think there are so many girls all over the world, but my Magda lives in Ukraine. I didn't think about the name at all: Magda immediately appeared because I love the name of Magdalyna very much". The idea to write a book appeared while walking with her son. They chanced to meet the girl on a wheelchair, and later they invented a story about her: how she imagines that she can fly and dreams of space and Antarctica.

Next book is about Birta Muller's son named Willi, who was born with Down's syndrome, and his mom decided to write a book that should help understand children with such condition better. It is important that the diagnosis of the main character is not mentioned in the book (only in the preface). According to the book, a boy is an alien. The book consists of 14 chapters, each of them tells about a separate period of Willi's life: birth, study and communication. He is not worse than others are, but is different: he sees and perceives this world in a different way, reacts differently to things, communicates and expresses emotions in a different way as well. The comparisons, which do not even hint at the inferiority of children with Down's syndrome, contribute to the formation of a tolerant attitude towards them.In fact, it's quite strange - trying to teach Willi to do everything as fast as we do. Maybe, we would rather try to do everything slower and calmer? Just like on Willi's planet.

Another book is a story about the girl named Carolyn, she is the same as her peers, only in a wheelchair. When she doubts whether she will succeed, she tells herself: "Yes! I can!" And she succeeds: she learns, plays, helps the teacher. Moreover, she is supported by parents and friends.

The last of mentioned above books is a trilogy for the little ones about life, illness, death, love and compassion. In the first book, we are introduced to the boy named Jacob and his family. His mom is pregnant, and he looks forward to seeing his sister. The parents tell him that the little sister will be born ill and will need special care. When the girl is born, Jacob notices that her fingers are like pearls. So, his little sister is named Pearl. The second book, Life of Pearl, tells the story of Jacob's first day at school. The boy realizes that his sister will never start walking, but he can wear her in his hands, but if she does not speak, he will read everything in her eyes. At school, he tells other children about Pearl and why she is special. In the third book, Pearl - Our Butterfly, she gets worse; the boy spends more time with his grandmother, who tells him about hospice care for the seriously ill. The little sister looks like a cocoon that will soon become a butterfly. Pearl dies in the spring, and it was the saddest day for the boy. The grandmother explained to him that it was time for his sister to leave. Jacob opens the window and sees a butterfly, which reminds him of his sister. He asks his grandmother whether they will remember her or they will pretend as if his sister has never existed. The grandmother assures him that this will never happen, because love cannot be forgotten.

Students read these books at home and the authors' biographies are read at lectures and taken from the textbook Literature and Inclusion. At practical lessons, we work with texts. Students read books and offer their own interpretations of the text. Someone draws a pyramid of a hero, someone creates calligraphy, someone a mental map, and someone offers a variant of creative game or swot analysis.

For the book "Just because" you have the following information:

Hero Pyramid:

Toby

Younger brother

Real and imaginary world

The sister who looks like a princess 
She cannot walk, talk and juggle

No one knows why... Just because...

Clemmie is not only the elder sister, but Toby's best friend

We also pointed out that the pyramid of the hero may contain not only sentences or phrases, but a list of words from which the associative series can be constructed.

Creative game:

$\mathrm{T}$ - teaches her sister

$\mathrm{O}$ - opens to Clemmie the whole world

$\mathrm{B}$ - bright character

$\mathrm{Y}$ - younger brother

Swot-analysis - Clemmie (Tab. 1)

\begin{tabular}{|l|l|}
\hline $\begin{array}{l}\text { The love and support of a younger brother is } \\
\text { - just because... }\end{array}$ & $\begin{array}{l}\text { She cannot do all that her brother can } \\
\text { - just because... }\end{array}$ \\
\hline $\begin{array}{l}\text { She can make Toby laugh, she can feel the } \\
\text { world by touching it, she can travel in the } \\
\text { imaginary world with her brother } \\
\text { - just because... }\end{array}$ & $\begin{array}{l}\text { She cannot be without brother's support } \\
\text { - just because... }\end{array}$ \\
\hline
\end{tabular}

Tab. 1. Swot-analysis. Clemmie

We have created the mental map on the basis of https://www.goconqr.com/ (Fig. 1)

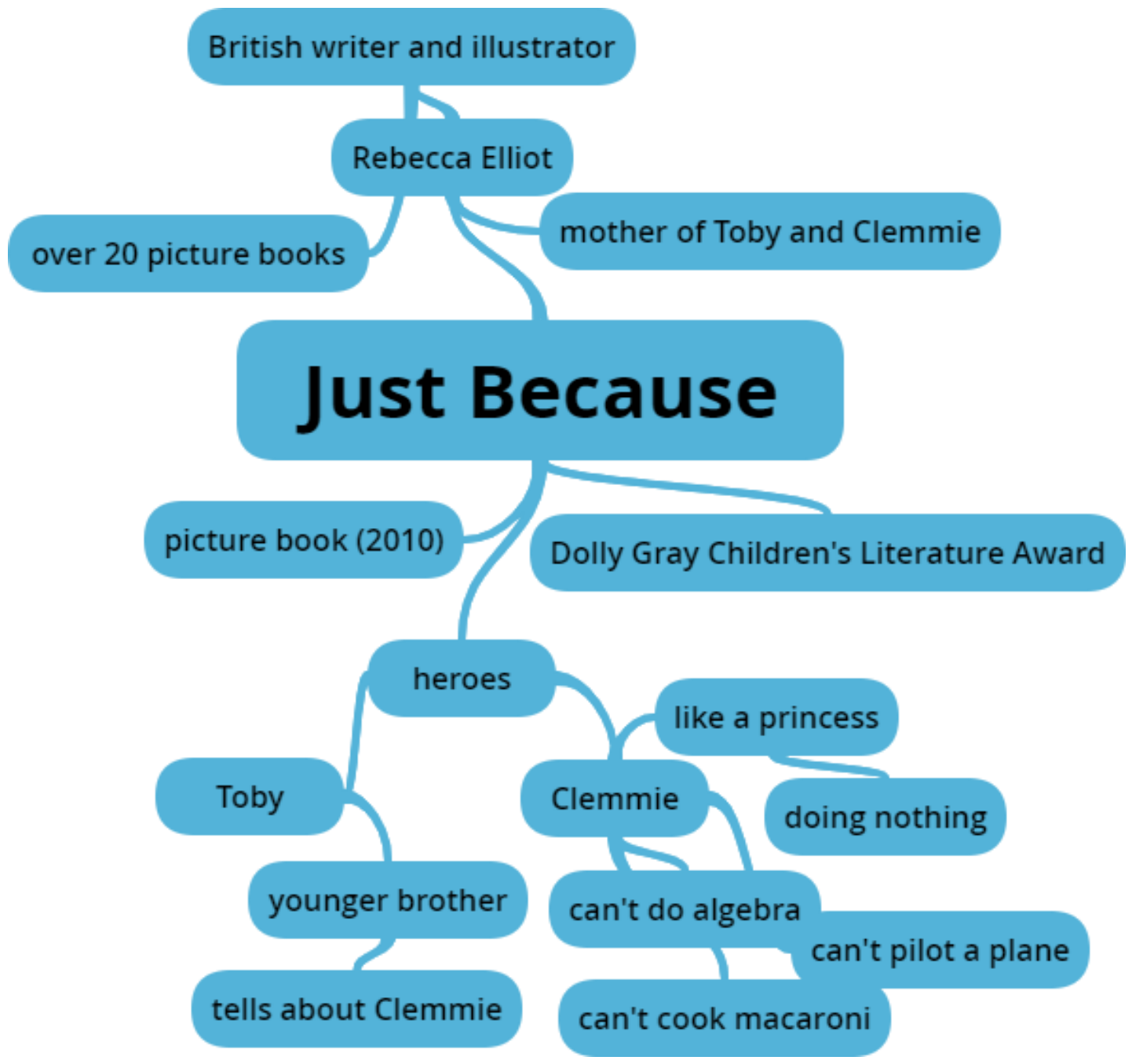

Fig. 1. Just Because. The mental map 
Next stage is the presentation of a book that was offered to analyze and explain the calligraphy, pyramid and others.

The students read the texts, also prepare episodes, comics, puzzles, crossword puzzles and clouds of words. These tasks do not cause much difficulty, as students use appropriate online generators. For example, a word cloud based on Pearl books is possible at the address: https://wordcloud.pro/en/studio/editor?v=7. It can be such words: Pearl, baby, Jacob, ordinary, butterfly.

Students explain why words become key in the cloud, and emphasize the symbolic representation of the cloud itself.

We can create the rebus by the name of the main character of the book "Just Because" (http://rebus1.com/ua) (Fig. 2):

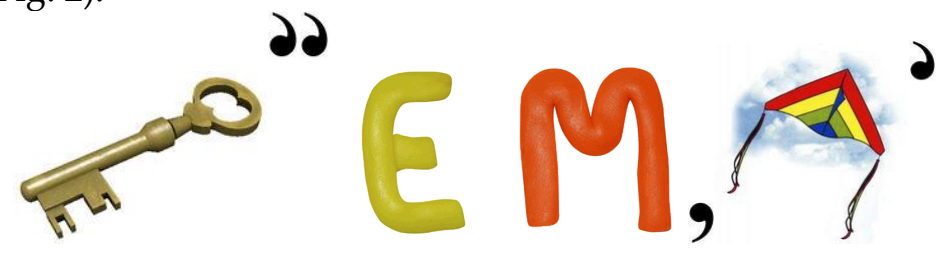

Fig. 2. Just Because. Rebus

Students can create comic episode according to the books (Fig. 3):

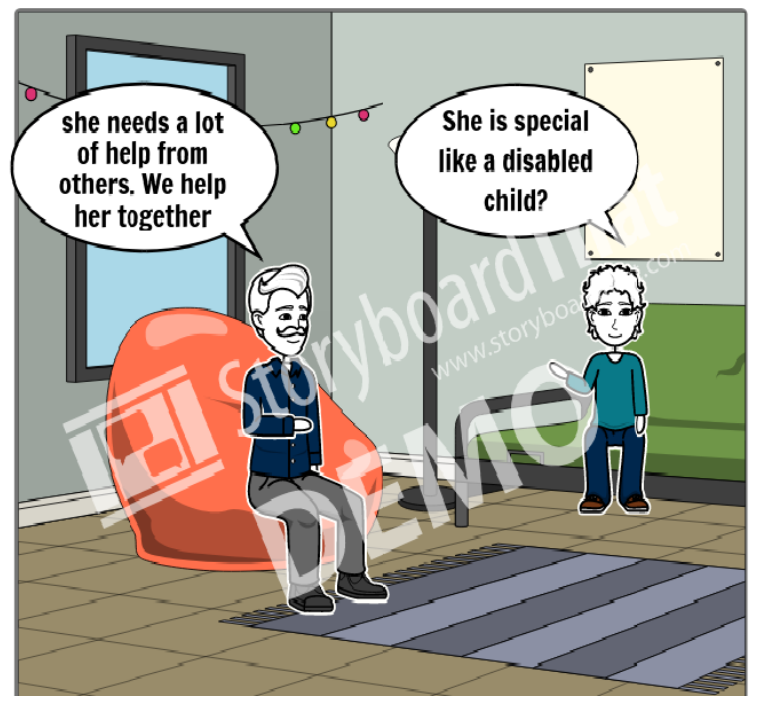

Fig 3. Pearl. Comic episode

According to this comic episode, it was necessary to recreate the episode from the book: who is talking to whom, whom this dialogue is about.

Of course, these types of work orient students to their future professional practice, because these strategies can be applied not only when working with texts, but also at any lessons.

At lessons students draw parallels between Ukrainian and foreign inclusive experiences, determine the problems of works, and discuss whether it is worth telling children about illnesses and death by means of a book or not. They draw attention to the fact that in most cases the push for writing such kind of literature is life situations in which the authors found themselves. Students noted that the authors of the stories we are speaking about are women who tell us about their personal experience. It should be noted that the books do not mention diagnoses; they introduce them as someone from another planet, someone who is like a princess and someone who is a bunny with a broken paw.

Mental maps are created not only for each book but also for all works where the concept of "inclusive literature for the youngest" is a key, because in these books one can trace the common features. Students create them either in a workbook or through an online resource. 
One more type of working with literature takes into account the method of "the six thinking hats" by Edward de Bono. It is necessary to be divided into six groups and to think what hat you will own. A white hat (thinking) - we focus on the facts. When was the book published and where? Is there a Ukrainian translation of the book? You can mention the genre and structure. A red hat (emotions) is the feelings that the book has caused. What emotions are in the book? A yellow hat (positive) - discussing what you liked the most in the book, captured, impressed. Black (critique) is a discussion of what you did not like, what you want to change in your variant. Green (creativity) - discussing the fate of characters. Blue (results) is what this book is about. Can you call the book to be motivating?

It is advisable to work with the text using the Walt Disney triangle but with several texts. The problem for discussion is formulated like that: "An ideal inclusive book for the youngest", the students are divided into groups of three people: a dreamer, a realist and a critic. The dreamer offers a variety and even unrealistic options. The realist structures his ideas, determines the necessary steps. The critic evaluates the quality of ideas and finds mistakes and gaps in decisions. The positive thing is that students pay attention to the important role of the book's narrator, for example, in "Just because" the story is told by a younger brother, it increases the level of intimation, as well as the activity of the following characters: Pearl, Willi, Clemmie, who are opened to the readers by family members, who tell us the story.

We teach the students to formulate questions about the text by means of Bloom's taxonomy daisy (a simplified version). Students receive a chamomile pattern with petals written in question schemes and formulate their own. The first type of questions is simple (book author, country, translation). The second type is to clarify (what book is about). The third type is to explain (why these characters not others). The fourth type is creative (what would be if...). Fifth type - evaluation (how well the author managed to realize his idea). The sixth type is practical (how would discuss this book with elementary school pupils).

Students are able to use vita holographic technologies to analyze different pieces of literature; so, the calligraphy, author or hero pyramids, and creative game are also possible. The students are especially fond of swot-analysis, providing many options for interpreting characters.

Another kind of working with a book is to create a lapbook that contains information about the book, as well as the tasks to check content knowledge. Students also create a scrapbook of the author or the main characters. It can be done at extracurricular classes and scrapbooks take place not only at the university but also at university street science picnics, where students tell young readers about inclusive books and their authors. One more type of work is to create posters based on the book you have read.

\section{CONCLUSIONS}

To conclude, working with the books in the way described above enables students to work with the texts much better, as well as to learn techniques that will be useful for them in the future practice. We prove when working with inclusive books for the youngest, students will present not only their ability to interpret the content, but also offer ways for working with the texts of this kind.

Unlike high school pupils, students at university pointed out that, the main characters of the books were children with disabilities and analyzed the principles of creating such books: to speak not about mutilation or disability, but otherwise, about absence of fake characters, the educational element of the fiction, the occasional happy end or a swirling dynamic plot. Moreover, the students noted that the purpose of such books - to tell children in an accessible way about diversity of the world, and spoke about the relevance of these books to certain age. For example, much discussion was provoked by the last chapter of the book about Pearl describing the death of the girl and how this loss is experienced by her brother. One of the students assured that it is worth talking about death and possible losses with the children, others did not agree, because we usually accept the children's books only as an optimistic and cheerful phenomenon. However, changing your attitude to children's books is just a matter of time. 
The main purpose of dealing with inclusive literature is to acquaint students with such literature, since it is actually absent in the curriculum, to draw more attention of society to the problems of people with disabilities, because fiction provides a glimpse into the inner world of the heroes; to look at society, which is not always ready to accept children with disabilities, as well as to prepare future teachers to read such books with their pupils.

The strategies of working with such literature help to become interested in fiction, to pay attention to details, to apply digital technologies and so on. In dealing with inclusive text, we do not focus on disability or character's illness. Nevertheless, of course, we discuss with students the peculiarities of creating such texts. Such strategies also help to focus on the text itself rather than trying to guess what the author wanted or did not want to say.

\section{REFERENCES}

[1] Andrews S.E. Using Inclusion Literature to Promote Positive Attitudes toward Disabilities. Journal of Adolescent $\mathcal{E}$ Adult Literacy, 41 (6) (1998), 420-426. Available at: https://www.jstor.org/stable/40016767

[2] Ayala E.C. "Poor little things" and "Brave little souls": The portrayal of individuals with disabilities in children's literature. Reading Research and Instruction, 39 (1) (1990), 103-117. doi: 10.1080/19388079909558314

[3] Barrett K., Freeland C., Toner J, Lemay V. Yes I Can!: A Girl and Her Wheelchair. Magination Press, 2018.

[4] Campbell K. Selecting Children's Books about People with Disabilities. Tennessee Libraries, 56 (1) (2006). Available at: https://www.tnla.org/page/24

[5] Drachkovska O. Cripple Bunny and his brave mother. Books - XXI, "Chorni vivtsi", 2019. (in Ukrainian)

[6] Drachkovska O. We have a change of concepts when anti-inclusion is given for inclusion. Available at: https://invak.info/intervyu/u-nas-isnuye-pidmina-ponyat-koli-antiinklyuziyu-vidayut-za-inklyuziyupismennicya-oksana-drachkovska.html (in Ukrainian)

[7] Elliot R. Just Because. Lion Children's Books, 2014.

[8] Luce K. Inclusive Literature: Choosing Resources to Represent Disability in the Classroom. Available at: http://etfovoice.ca/feature/inclusive-literature

[9] Lushchevska O., Haidamaka E. Trustees for the Giraffe. The Old Lion Publishing House, Lviv, 2018. (in Ukrainian)

[10] Morykvas I. Magda and the Wind. A-ba-ba-ha-la-ma-ha, Kyiv, 2017. (in Ukrainian)

[11] Müller B. Planet Willi. Beltz \& Gelberg, 2015 (in German)

[12] Osmolovska O. Formation of the Ukrainian Inclusive Literature Direction as the New Publishing Trend. Integrated communications, (2017), 27-32. Available at: http://elibrary.kubg.edu.ua/id/eprint/25868/1/O_ Osmolovska_4_17_IC_BHKU.pdf (in Ukrainian)

[13] Osmolovska O. Is Inclusive Literature a Must or Need? Available at: https://blog.liga.net/ user/oosmolovska/article/22995 (in Ukrainian)

[14] Pere T., Flores C. Pearl's Life (Pearl). Wickwick Ltd, 2019.

[15] Pere T., Flores C. Pearl, Our Butterfly. Wickwick Ltd, 2019.

[16] Pere T., Flores C. Welcome Home, Pearl. Wickwick Ltd, 2019.

[17] Prater M.A. Learning Disabilities in Children's and Adolescent Literature: How Are the Characters Portrayed? Learning Disabilities Quarterly, 26 (1) (2003), 47-62. Doi: 10.2307/1593684

[18] Sharon A. H. Inclusion Literature: Ideas for Teachers and Teacher Educators. Electronic Journal For Inclusive Education, 1 (8) (2004). Available at: https://corescholar.libraries.wright.edu/cgi/ viewcontent.cgi?article $=1052 \&$ context $=$ ejie

[19] Topol V. Some non-obvious theses on inclusive education. Available at: http://nus.org.ua/articles/kilkaneochevydnyh-tez-pro-inklyuzyvnu-osvitu/ (in Ukrainian) 
[20] "Trustees for the Giraffe": a book about eco-responsibility and inclusion. Available at: https://starylev.com.ua/news/opikuny-dlya-zhyrafa-knyzhka-pro-eko-vidpovidalnist-ta-inklyuziyu (in Ukrainian)

[21] Why Swot Analysis Sucks - And How To Make It Better With Future Trends. Available at: https://www.competitivefutures.com/swot-analysis-sucks-future-trends/

Address: Olga Derkachova, Oksana Tytun, Vasyl Stefanyk Precarpathian National University, 57, Shevchenko Str., Ivano-Frankivsk, 76018, Ukraine.

E-mail: olga_derkachova@ukr.net

Received: 17.12.2019; revised: 24.02.2020.

Деркачова Ольга, Титунь Оксана. Інноваційні методи роботи з художнім текстом (на матеріалі дитячої інклюзивної літератури). Журнал Прикарпатського університету імені Василя Стефаника, 7 (1) (2020), 102-111.

Дослідження присвячене аналізу інноваційних методів роботи 3 художнім текстом зі студентами педагогічних спеціальностей. Ілюстративним матеріалом слугують інкдюзивні книги для найменших вітчизняної та зарубіжної літератури: "Зайчик-нестрибайчик та його смілива мама", “Магда і вітер”, “Опікуни для жирафа”, “Просто тому що”, “Планета Вілді”, “Так! Я можу!", тридогія про Перл. Головними героями цих творів виступають діти з інвалідністю та особливими освітніми потребами, а оповідачами часто стають старші або менші брати чи сестри. Вибір інкдюзивної літератури зумовлений тим, що це нові актуальні художні твори, які відображають світ дітей 3 інвалідністю, говорять про важдиві та серйозні теми, як-от тема смерті, а також мають на меті показати, що краса світу у його різноманітності. Розглянуто впровадження вітагенних технологій 3 годограмним проєктуванням (каліграма, креативна гра, піраміда автора та героя). Обгрунтовано доцільність застосування методик критичного мислення під час аналізу художнього тексту (ромашка Блума, шість капелюхів, майндмапінг, swot-аналіз, трикутник Волта Діснея). Також розглянуто можливості застосування онлайнресурсів під час роботи з дітературними творами (генератор ребусів, коміксів, створення ментальних карт, кросвордів на онлайнплатформі). Доведено, що такі методи роботи сприяють розвитку читацьких інтересів, креативного мислення, допомагають розкрити творчий потенціал студентів, дозволяють по-новому подивитися на художній текст. Вони стануть у нагоді в подальшій професійній діяльності майбутніх вчителів.

Ключові слова: інклюзивна література, піраміда героя, креативна гра, майндмапінг, swotаналіз, шість капелюхів, ромашка Блума, комікс, ребус, трикутник Волта Діснея. 